\title{
AVALIAÇÃo SENSORIAL DE PÉ DE MOLEQUE PRODUZIDOS COM NOZ MACADÂMIA E AÇÚCAR LIGHT
}

\author{
Bárbara Côgo Venturim 1 \\ Jeferson Alves Bozzi ${ }^{2}$ \\ Viviani Baptista Bueno ${ }^{3}$ \\ Adriane Bernardo de Oliveira Moreira ${ }^{4}$ \\ Fabiana Carvalho Rodrigues ${ }^{5}$ \\ Evandro de Andrade Siqueira ${ }^{6}$ \\ Deusélio Bassini Fioresi ${ }^{7}$ \\ Lucas Louzada Pereira ${ }^{8}$
}

Resumo: Esse estudo objetivou verificar a aceitação sensorial através da escala hedônica de quatro formulações diferentes de pé de moleque, elaboradas com amendoim, macadâmia, açúcar light e açúcar convencional. A avaliação sensorial foi realizada em cabines individuais com 50 provadores não treinados, do sexo feminino e masculino, e maiores de 18 anos. O resultado da análise sensorial foi de extrema importância, pois mostrou que o açúcar light exerceu efeito significativo na textura e no sabor das amostras de pé de moleque. A macadâmia não exerceu influência significativa na aceitação do produto pelos consumidores, sendo tão aceito quanto o pé de moleque contendo amendoim. Porém nota-se a carência em estudos que envolvam a utilização da noz em inovações de formulações alimentícias, assim como, sua viabilidade econômica, pois se trata de um produto com preço elevado.

Palavras-chave: Pé-de-moleque; Macadâmia; Light; Analise Sensorial; Açúcar convencional.

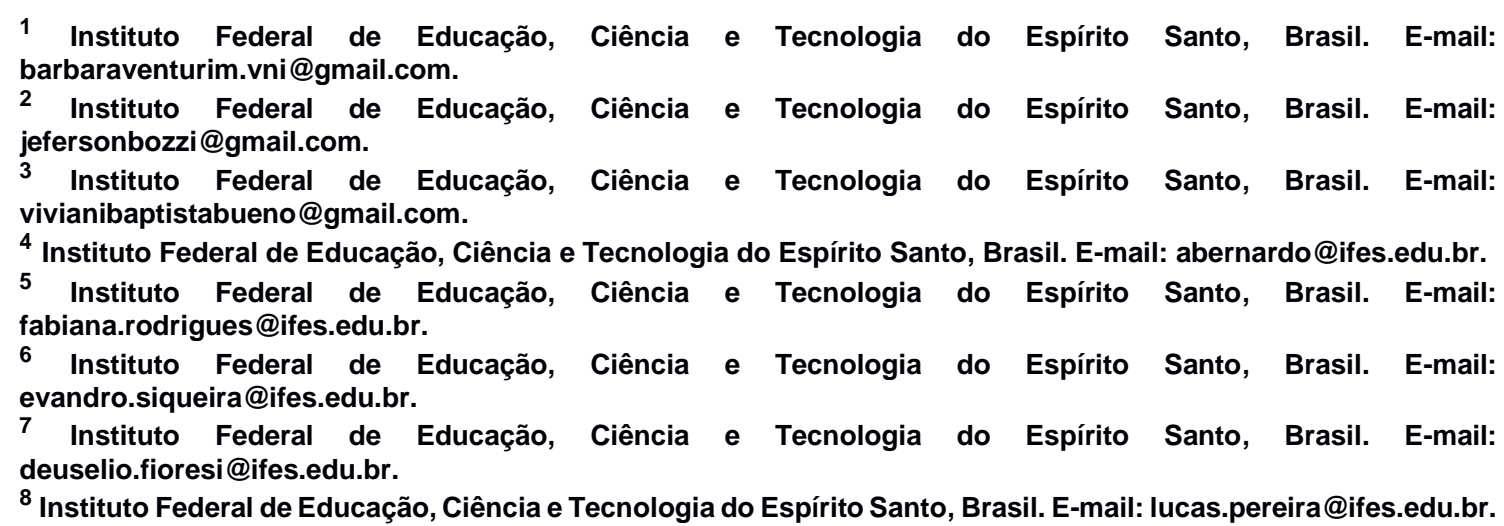

